УДК 793.31(477)"1921/1991"

DOI: $10.31866 / 2616-7646.2 .2 .2019 .188814$

\title{
ВІРТУОЗНІСТЬ В АНСАМБЛЯХ НАРОДНОГО ТАНЦЮ УКРАЇНИ РАДЯНСЬКОї ДОБИ
}

\author{
Морозов Артем Ігорович, \\ кандидат мистецтвознавства, \\ Київський національний університет культури і мистецтв, \\ Київ, Україна, \\ https://orcid.org/0000-0003-0598-5702, \\ tema.morozov17agmail.com
}

\begin{abstract}
Мета дослідження - виявити основні аспекти розвитку віртуозності в ансамблях народного танцю України радянського періоду. Методологія. Застосовано історичний метод для об’єктвного розгляду історико-політичного контексту; проведена систематизація відомостей щодо віртуозних рухів у танцях різних балетмейстерів; використано мистецтвознавчий аналіз народно-сценічних танців з метою виявлення віртуозної хореографічної лексики. Наукова новизна. Уперше проаналізовано віртуозну лексику українського народно-сценічного танцю в діяльності ансамблів народного танцю України за радянської доби крізь історико-культурну призму. Висновки. У річищі соціалістичного реалізму, проголошеного провідним естетико-культурним орієнтиром мистецької сфери на початку 30-х pp. XX ст. в СРСР, створення професійних та аматорських ансамблів народного танцю відбулося під гаслом збереження національної ідентичності. Одночасно український народно-сценічний танець перетворювався на один з інструментів радянської пропаганди. Творчість К. Балог, К. Василенка, П. Вірського, Л. Калініна, А. Кривохижі, В. Петрика, Я. Чуперчука та інших балетмейстерів в аматорських та професійних ансамблях народного танцю за радянської доби дозволяє вести мову про виокремлення феномену віртуозності в народно-сценічному танці, що є віддзеркаленням однієї із провідних тенденцій хореографічного мистецтва - ускладнення лексики народно-сценічного танцю. У контексті мистецтва соціалістичного реалізму феномен віртуозності мав суперечливу природу: з одного боку, ускладнення традиційних і використання нових віртуозних рухів з арсеналу класичного балету, взаємодія зі спортом засвідчували процес розвитку віртуозної лексики народно-сценічного танцю, збагачення його виражальних засобів; з іншого боку - віртуозність у радянську добу виступає замінником вихолощеного традиційного змісту народного танцю.
\end{abstract}

Ключові слова: український народно-сценічний танець, віртуозність, віртуозні рухи, ансамбль народного танцью, хореографія. 


\section{ВИРТУОЗНОСТЬ В АНСАМБЛЯХ НАРОДНОГО ТАНЦА УКРАИНЫ СОВЕТСКОЙ ЭПОХИ}

\author{
Морозов Артем Игоревич, \\ кандидат искусствоведения, \\ Киевский национальный университет \\ культуры и искусств, \\ Киев, Украина, \\ https://orcid.org/0000-0003-0598-5702, \\ tema.morozov17agmail.com
}

Цель исследования - выявить основные аспекты развития виртуозности в ансамблях народного танца Украины советского периода. Методология. Применен исторический метод для объективного рассмотрения историко-политического контекста; проведена систематизация сведений про виртуозные движения в танцах разных балетмейстеров; использован искусствоведческий анализ народно-сценических танцев с целью выявления виртуозной хореографической лексики. Научная новизна. Впервые проанализировано виртуозную лексику украинского народносценического танца в деятельности ансамблей народного танца Украины в советское время через историко-культурную призму. Выводы. В русле социалистического реализма, провозглашенного ведущим эстетико-культурным ориентиром художественной сферы в начале 30-х гг. XX в. в СССР, создание профессиональных и любительских ансамблей народного танца произошло под лозунгом сохранения национальной идентичности. Одновременно украинский народно-сценический танец превращался в один из инструментов советской пропаганды. Творчество К. Балог, К. Василенко, П. Вирского, Л. Калинина, А. Кривохижа, В. Петрика, Я. Чуперчука и других балетмейстеров в любительских и профессиональных ансамблях народного танца в советское время позволяет вести речь о выделении феномена виртуозности в народно-сценическом танце, что является отражением одной из ведущих тенденций хореографического искусства - усложнения лексики народно-сценического

\section{VIRTUOSITY IN UKRAINE'S FOLK DANCE ENSEMBLES OF THE SOVIET ERA}

\author{
Artem Morozov, \\ $\mathrm{PhD}$ in Arts, \\ Kiev National University \\ of Culture and Arts, \\ Kiev, Ukraine, \\ https://orcid.org/0000-0003-0598-5702, \\ tema.morozov17agmail.com
}

The purpose of the article is to identify the main aspects of the development of virtuosity in folk dance ensembles of Ukraine of the Soviet era. Methodology. The historical method is applied for an objective consideration of the historical and political context; systematization of information about virtuoso movements in the dances of different choreographers; an art criticism analysis of folk stage dances was used to identify virtuosic choreographic vocabulary. Scientific novelty. For the first time, the virtuoso vocabulary of Ukrainian folk dance was analyzed in the activity of folk dance ensembles of Ukraine in Soviet times through a historical and cultural prism. Conclusions. In line with socialist realism, proclaimed the leading aesthetic and cultural landmark of the artistic sphere in the early 30s. XX century in the USSR, the creation of professional and amateur folk dance ensembles took place under the slogan of preserving national identity. At the same time, Ukrainian folk stage dance turned into one of the instruments of Soviet propaganda. The works of K. Baloh, K. Vasylenko, P. Virskyi, L. Kalinin, A. Kryvokhyzh, V. Petryk, Y. Chuperchuk and other choreographers in amateur and professional folk dance ensembles in Soviet times allow us to talk about highlighting the phenomenon of virtuosity in folk stage dance, which is a reflection of one of the leading trends in choreographic art - the complication of vocabulary of folk stage dance. In the context of the socialist realism art, the phenomenon of virtuosity was of a contradictory nature. On the one hand, there was a complexity of traditional and use of new virtuosic movements from the arsenal of classical ballet, interaction with 
танца. В контексте искусства социалистического реализма феномен виртуозности имел противоречивую природу: с одной стороны, усложнение традиционных и использование новых виртуозных движений из арсенала классического балета, взаимодействие со спортом свидетельствовали о процессе развития виртуозной лексики народно-сценического танца, обогащении его выразительных средств; с другой стороны - виртуозность в советские времена выступает заменителем выхолощенного традиционного содержания народного танца. sports testified to the development of virtuoso vocabulary of folk stage dance, enrichment of its expressive means, on the other, virtuosity in Soviet times is a substitute for the emasculated traditional content of folk dance.

Key words: Ukrainian folk stage dance, virtuosity, virtuoso movements, folk dance ensemble, choreography.

Ключевые слова: украинский народно-сценический танец, виртуозность, виртуозные движения, ансамбль народного таниа, хореография.

Актуальність теми дослідження. Український народний танець насичений різноманітними лексичними утвореннями, які можна віднести до складно-технічних, віртуозних - стрибки, повзунки, оберти тощо. Попри умовність поняття «віртуозний», що носить конкретно-історичний характер, віртуозність сфери народно-сценічного танцю заслуговує на самостійне дослідження. Радянський період став важливим етапом формування та розвитку сценічних форм віртуозних рухів народного танцю, саме тоді були створені й підтримувалися державою професійні та аматорські колективи народного танцю. Важливим ракурсом дослідження віртуозності є встановлення кореляційних зв'язків між соціокультурним контекстом і творчістю ансамблів народного танцю за радянських часів.

Аналіз останніх досліджень і публікацій. Попри значний масив праць, котрі повністю присвячені або торкаються проблем українського народно-сценічного танцю радянської доби (К. Василенко (1996), П. Вірський (1960), Н. Кіптілова (2014), В. Литвиненко (2009), А. Підлипська (2018), В. Шкоріненко (2003) тощо), зокрема й наші наукові розвідки (Морозов, 2017), спеціального дослідження проблеми віртуозності в ансамблях народного танцю України радянської доби з урахуванням зв’язків із соціокультурним контекстом виявлено не було.

Мета дослідження - виявити основні аспекти розвитку віртуозності в ансамблях народного танцю України радянського періоду.

Виклад основного матеріалу. Більшовицькі перетворення в Україні були від початку спрямовані на системний злам традиційної культури. «Місце гуманітарної культури зайняла марксистсько-ленінська теорія в тому канонізованому і догматизованому вигляді, в якому вона найбільше годилася для ролі політичної релігії і знаряддя політичної інквізиції, - відзначає М. Попович. - Руйнація продуктивних сил села і традицій селянської культури з її моральним потенціалом нищили фундамент національної культури в цілому» (Патон та ін., 2011, с. 180). 
Відомо, що танець відображає характер народу, його історію й правду життя. У більшовицькій імперії, до складу якої після поразки національно-визвольних змагань приєднали Україну, перед хореографічним мистецтвом були поставлені інші завдання: танець мав відбивати не національний характер, яким він був насправді, а ідеологічне трактування цього характеру, визначене в засадничих принципах національної політики більшовицької партії; не історію народу, а їі шовіністичну радянську версію; не правду життя, а пропагандистський кремлівський міф.

Характерною рисою молодого радянського мистецтва, особливо його радикально-революційних течій, було проголошення розриву із традиціями (В. Василько в театральному мистецтві, Г. Михайличенко і М. Семенко в літературі та ін.). Гострі дискусії точилися у 1920-х роках довкола проблеми взаємодії традицій і новаторства (М. Хвильовий, Л. Курбас). Втручання московської влади поклало край цим дискусіям, а голодомор 1932-1933 рр. і Великий терор придушили опір українського селянства як основного носія національної ідентичності й української інтелігенції як носія національної ідеї. У другій половині 1930-х років в УРСР остаточно сформувався тоталітарний режим, «у якому всі громадські прояви життя кожної людини перебувають під державним контролем, кожен дійсний чи уявний відступ від норм нещадно карається терористичними засобами» (Патон та ін., 2011, с. 159).

Творення соціалістичної культури насамперед передбачало нещадну боротьбу із «проявами ворожої ідеології» - «українського буржуазного націоналізму», який викорінювали по всій лінії «культурного фронту». Єдиним для представників усіх видів мистецтва був проголошений «метод соціалістичного реалізму». У форматі цього методу були змушені працювати й діячі хореографічного мистецтва. Згідно із засадничими догматами соцреалізму, радянське мистецтво мало бути «національним за формою і соціалістичним за змістом», будуватися за «принципами партійності й народності». У вимірах народно-сценічної хореографії це означало, що традиційна форма народного танцю відривалася від його традиційного змісту, що перекреслювало узвичаєний - від І. Котляревського до В. Верховинця - підхід до сценізації народного танцю; також замість засобу збереження національної ідентичності український народно-сценічний танець перетворювався на один з інструментів радянської пропаганди.

Для реалізації партійних настанов стосовно правильного використання хореографічного фольклору й творення радянського народно-сценічного танцю на його основі 1937 р. у Москві був заснований Ансамбль народного танцю СРСР під керівництвом I. Моісєєва, того ж року у Києві - Ансамбль народного танцю УРСР під керівництвом Павла Вірського. Одним із мотивів для організації Ансамблю народного танцю УРСР було, на нашу думку, прагнення протиставити радянський народний танець хореографічним постановкам В. Авраменка, які тлумачилися як буржуазно-націоналістичні. У сучасній хореографічній літературі й довідкових виданнях доволі часто стверджується, що названий ансамбль заснував чи створив П. Вірський у співпраці з М. Болотовим. Але зрозуміло, що рішення приймалося у владних кабінетах на реалізацію культурної політики більшовиків, що передбачала одержавлення всієї сфери радянської культури. «У річищі тодішнього культуртрегерства при клубах та будинках культури створювалися схожі один на 
одного, неначе краплини води, самодіяльні ансамблі народного танцю (або пісні й танцю), - відзначає О. Різник (1998). - А над ними до кінця 30-х років сформувалася мережа “зразково-показових” професійних народно-хореографічних колективів, що мали не просто демонструвати розквіт національних культур СРСР, а й вказувати власним громадянам, що і як мусить танцювати радянська людина» (с. 647-648). П. Вірський був змушений творити в умовах суворого контролю, що стримувало творчу ініціативу не тільки в час Великого терору, коли ансамбль було засновано, а й у подальші роки.

У всесоюзній та республіканській пресі періодично з'являлися відгуків про виступи ансамблю П. Вірського. Так, рецензент А. Посадов (1937), вітаючи перший виступ новоствореного ансамблю, відзначає як складник успіху не тільки «ідейну стилістичну цілеспрямованість», а й те, що «ансамблеві вдалося зняти намул вульгаризму з деяких народних танців, прекрасних за своєю природою, але деякою мірою спаплюжених псевдонародним виконанням різними “липовими” естрадниками». Оцінка А. Посадова (1937) перегукується з оцінкою виступу українських танцюристів на Першій декаді літератури і мистецтва УРСР у Москві, яку дав голова Комітету в справах мистецтва при Раднаркомі СРСР П. Керженцев (1936): «Українські танці полонили глядачів своєю безпосередністю, реалізмом, близькістю до народного танцю. От де вже не було сусальності, пейзанства, підробки під “народ”».

Ці та інші відгуки в партійній пресі нібито свідчать про те, що позиція керівництва цілком збігалася з позицією В. Верховинця, котрий послідовно виступав проти псевдонародних підробок, вульгаризації, стилізації, «пейзанства» тощо (Рильський, 1990, с. 5-6). Однак була й суттєва відмінність: партійне та державне керівництво «культурним фронтом» вбачало в народному танцеві засіб утвердження радянськості, а В. Верховинець - українськості, що й спричинило репресивні заходи стосовно першого українського етнохореографа. Радянське керівництво по-своєму дбало про лексичну чистоту, розширення пластичного арсеналу народного танцю за рахунок використання складно-технічних рухів. Однак кардинально відмінними були уявлення про те, які ідеї має утверджувати балетмейстер мовою танцю. Українські митці були переконані, що мова танцю має відбивати характер, звичаї, обряди. Культурна політика більшовицької влади ставила перед народно-сценічною хореографією принципово інші завдання: утверджувати радянські звичаї та обряди, уславлювати «щасливе життя», «нерушиму дружбу» і т. п. Радянська пропаганда доводила, що всі народи СРСР мають спільну історію, започатковану «більшовицькою ерою», спільне устремління і «світле майбутнє», бо всі вони становлять «нову історичну спільність - радянський народ». Не варто доводити, що поняття «радянський народ» у рефлексії світової спільноти ототожнювалось із поняттям «російський народ». Творці радянської культурної політики й мистецтвознавці вважали танець «зброєю», але, на відміну від В. Авраменка та В. Верховинця, не національною, а більшовицькою, спрямованою проти національної окремішності, національного менталітету.

Зрозуміло, що постановки на актуальні теми радянської історії і сучасності були для балетмейстерів необхідною умовою перебування у професії, забезпечували громадянський імунітет. «Під прикриттям» постановок на революційну, 
оборонну, колгоспну, робітничу тематики українські балетмейстери радянської доби створювали справжні зразки народно-сценічного танцю.

Творчість П. Вірського стала епохою в розвитку українського сценічного танцю. Інтегрувавши творчий досвід попередників - В. Верховинця, М. Соболя та інших, він, за визначенням М. Вантуха (2002), створив «якісно нову танцювальну мову - лексику сучасної української народно-сценічної хореографії» (с. 19). Вагоме місце у створеній П. Вірським новій танцювальній мові відводиться віртуозним рухам, трюковій техніці. Творчий метод балетмейстера, як відомо, базувався на поєднанні техніки народного танцю і класичного балету. Працюючи з 1928 р. в Одеському театрі опери і балету танцівником-прем'єром, а водночас постановником таких балетних вистав, як «Лебедине озеро», «Дон Кіхот», «Корсар», «Червоний мак» та ін., П. Вірський блискуче оволодів мовою класичного балету, розкрив для себе глибинні основи драматургії великої балетної вистави. Цей досвід значною мірою посприяв новому баченню можливостей театралізації народного танцю. Характеризуючи особливості підходу П. Вірського до фольклорного матеріалу, М. Вантух (2002) відзначає: «З українського танцювального фольклору, що завжди був животворним джерелом творчості балетмейстера, він черпав лише окремі рухи й композиції, лише так звану коротку танцювальну тему, тобто своєрідну пластичну мелодію, i, відштовхуючись від цього, створював широке і вражаюче хореографічне полотно, неперевершену і самобутню симфонію народного танцю» (с. 19).

Аналогічним чином П. Вірський осмислював кожен танцювальний рух: він розширював амплітуду рухів, трансформуючи прості рухи у складно-технічні, створював нові різновиди віртуозних рухів, виявляючи надзвичайну винахідливість і художній такт у використанні трюків. При цьому віртуозність ніколи не була самоціллю балетмейстера. «У хороших традиціях українського танцю такі технічно складні рухи, як “повзунець”, різноманітні присядки, обертання в присядці та в повітрі, стрибки, повороти, - наголошував П. Вірський. - Однак користуватися ними слід так, щоб вони були природною кульмінацією танцю, а не “стороннім тілом”, зовсім не пов’язаним із його розвитком і характером» (Вірський, 1960).

П. Вірський осмислював танцювальний рух у його еволюційному розвиткові, розкриваючи закладений у ньому художній і технічний потенціал. Так, у «повзунці» митець побачив матеріал для створення віртуозного, цілісного за стилістикою й технікою виконання танцю «Повзунець». К. Василенко (1996) назвав «Повзунець» П. Вірського класичним зразком побудови танцю на трансформації окремого елементу руху (с. 147). Коли врахувати, що «повзунець» як рух уперше описав у «Теорії українського народного танцю» В. Верховинець (1990), завдяки творчому підходу П. Вірського перед нами відкривається картина еволюції традиційного елементу пластичного мистецтва від фольклорного зразка до віртуозного танцю, в якому «повзунець» використовується у різних ускладнених технічно варіантах. На матеріалі одного фольклорного руху П. Вірський поставив і танець «Плескач», котрий, як і «Повзунець», увійшов до золотого фонду національного хореографічного мистецтва.

Унікальною рисою української народної хореографії є велика кількість різноманітних стрибків, повітряних турів, а також присядок. У поставлених П. Вірським «Гопакові», хореографічних картинах «Запорожці» й «Чумацькі радощі» де- 
монструється цілий каскад віртуозних рухів, художньо вмотивованих характером видовища - виявом невтримної веселості у «Гопакові», героїкою військового побуту в «Запорожцях», світлим, щирим українським гумором у «Чумацьких радощах». Розуміючи необхідність сценічної презентації українських танців зі зброєю, П. Вірський показав у «Запорожцях» близько 30 вправ зі списами, що стало справжньою знахідкою, тому що не тільки в народно-сценічній хореографії, а й у класичному балеті цей вид холодної зброї, на відміну від мечів, шабель, кинджалів, майже не використовувався при постановці віртуозних танців.

Як відомо, віртуозність притаманна українському чоловічому танцю значно більшою мірою, ніж жіночому, котрий, за всієї розкутості (особливо порівняно 3 російським жіночим плясом і жіночими танцями народів Кавказу), відзначається стриманістю рухів. П. Вірський збагатив арсенал жіночої пластики, доповнивши її технічно складними рухами, що споріднені з фольклорним матеріалом. Із надзвичайним художнім тактом і смаком використані елементи віртуозної техніки у мініатюрах «Ляльки», «Рукодільниці», «Подоляночка».

Віртуозність у тлумаченні П. Вірського була потужним засобом театралізації танцю, посилення видовищності вистави. Невимушене виконання віртуозних рухів і вигадливих трюків у постановках П. Вірського базувалося на високій технічній підготовці всіх учасників очолюваного ним ансамблю. Численні захоплені відгуки у вітчизняній та зарубіжній пресі, зокрема, наведені Г. Боримською (1974) в праці «Самоцвіти українського танцю» та В. Литвиненком (2009) у статті «Творчість П. П. Вірського у світовому інформаційному просторі», засвідчують, що глядач сприймав віртуозність у постановках майстра як маніфестацію високого рівня української хореографічної культури.

Творчість П. Вірського стала найвищим досягненням української народно-сценічної хореографії радянської доби, зразком для багатьох колективів, вона визначила провідний напрям розвитку цього різновиду хореографічного мистецтва, окресливши продуктивні методи обробки фольклорного матеріалу. Підходи, знахідки майстра більшою чи меншою мірою вплинули на роботу кожного українського балетмейстера, допомагаючи в пошуках власного стилю, власної пластичної мови, нових рішень у використанні віртуозної техніки з метою розкриття краси народного танцю. Водночас радянські балетмейстери, як і П. Вірський, стилістику танцю, допустиму в мистецтві соціалістичного реалізму, черпали з фольклорних джерел.

Знакову тему українського мистецтва - тему запорожців - глибоко розкрили П. Вірський, Л. Калінін, В. Михайлов, О. Опанасенко. Характерною ознакою цих чоловічих танців є насиченість віртуозними рухами, акробатичними елементами, трюковою технікою з використанням зброї тощо. Аналізуючи хореографічний текст твору П. Вірського «На Січі Запорозькій», К. Василенко (1996) зазначає: «Загалом козаки виконують 20 вправ зі списами, у I дії деякі рухи із шаблями. Друга дія - танець-перепляс старих підпилих козаків. Потім - жарти і цілий каскад віртуозних рухів у запорозькому бойовому танці: повітряні рухи-стрибки, кабріолі, присядки-закладки, стрибки через шаблі, імітування скачки верхи з канчуком у правиці і далі цілий каскад карколомних рухів, що демонструють силу і спритність, хист, надзвичайно високу фізичну підготовку запорожців. Лексика: найріз- 
номанітніші присядки, козацький падебаск, кабріолі, содебаски, закладки, млинок, кубарик, бедуїнське тощо» (с. 97).

у 1958 р. в Державному заслуженому академічному народному хорі імені Г. Верьовки була створена вокально-хореографічна композиція «Запорожці» в постановці Л. Калініна. Особливість композиції полягає в тому, що це - жанрова картинка, а не монументальне полотно, як часто вирішували цю тему. Прообразом «Запорожців» був танець «Вільний козак», побудований на фольклорному матеріалі. На пропозицію Г. Верьовки була створена вокально-хореографічна композиція. Після пісні «Гей, літа орел» полковник закликає козаків до танцю, спочатку - веселі витівки жартівників, змагання між полковником і сотником, а згодом - мужній віртуозний танець «Козак» (Колосок, 2002, с. 26-27).

По-іншому, ніж бойовий танець запорожців, створений у постановках українських балетмейстерів парубоцький «Гопак». У ньому використовуються ті ж віртуозні елементи, що й у запорозькому «Козакові» - найрізноманітніші стрибки, тинки, присядки, повзунці тощо, однак це інший танець, занурений у стихію веселощів, він демонструє здоров'я, фізичну силу, життєлюбство, невтримний молодечий запал, втілений у складній ритмопластичній образності, що у віртуозних па кульмінаційного моменту досягає свого апогею. Парубоцький «Гопак» позбавлений тієї грізної внутрішньої сили і войовничості, яка властива запорозькому танцеві, адже це танці представників різних суспільних станів: озброєного українського лицарства - і сільської молоді.

У балетмейстерській практиці радянської доби назва танцю - «Козак» - не використовувалась, вона була замінена назвою «Гопак». Не вступаючи в започатковану В. Купленником полеміку щодо використання назв «Козак» $\mathrm{i}$ «опак» (Купленик, 1997), відзначимо доцільність виокремлення військових українських танців як жанру. До нього, окрім козацьких, належать бойові танці Карпатського регіону, поставлені В. Петриком («Довбуш»), Я. Чуперчуком («Довбуш», «Опришки», «Аркан») та ін. Характерною особливістю цих танців $є$ віртуозність рухів зі зброєю гуцульськими топірцями, використання складно-технічних лексичних конструкцій, елементів акробатики, трюкової техніки.

Віртуозні рухи з предметами (сокирками, палицями, батогами) використано в постановках В. Петрика «Чабан», «Лісоруби», записаному К. Василенком і поставленому Н. Уваровою старовинному пастушому танці «Коша». У першій частині композиції «Коша», що представляє пастуші ігри, використано підсічку з батогом, присядку-розніжку з батогом, різноманітні підскоки-підсічки з батогом (Василенко, 1996, с. 69-70). Використання емблематичного пастушого знаряддя - батога - урізноманітнює техніку пластичних рухів, підсилює регіональний колорит старовинного пастушого танцю степової України.

Із джерел хореографічного фольклору Карпатського регіону черпає пластичні образи К. Балог у композиції «Вівчар на полонині», поставленій у Закарпатському заслуженому народному хорі України. Розвиваючи тему хореографічної картини, К. Балог ускладнює традиційні стрибкові рухи, властиві гуцульському танцю «гвинт», «свердло», «присядку-“м'ячик”», доречно вводить трюкові елементи стрибки на руках, перекочування по колу на спині та ін.

Витоки чоловічого карпатського танцю «Гора» («Вежа», «Дзвіниця») губляться у глибині століть. Цей яскравий фольклорний матеріал блискуче, в різних варі- 
антах сценізували К. Балог, М. Вантух, Д. Ластівка і В. Петрик. Виконання «двоярусного» танцю, що потребує не тільки віртуозної техніки, а й артистизму (інакше танець може перетворитися на акробатичний номер), є яскравим свідченням розвитку віртуозної техніки в українському народно-сценічному мистецтві.

Надзвичайно багатий ігровий фольклор українців надихнув А. Кривохижу на створення колоритних хореографічних картин у композиції «Ятранські весняні ігри». Матеріалом для твору послужили записи хореографічного фольклору, зроблені балетмейстером у селі Перегонівка та в інших селах, де він перебував під час польових досліджень. Поєднання парубоцьких розваг, змагань у віртуозному танцюванні з дівочими хороводами створюють насичену, яскраву і правдиву картину зустрічі весни. Перекладаючи ігрові рухи парубків на мову хореографії, А. Кривохижа мотивовано використовує віртуозні рухи, елементи трюкової техніки.

Матеріалом для створення «Українського весільного танцю» послужив К. Василенку запис колгоспного весілля, зроблений ним під час експедиції до села Аули Криничанського району Дніпропетровської області. У коментарі до твору балетмейстер зазначає: «Це один із небагатьох танців, у якому повністю показано засобами хореографії весільний обряд, із дійовими особами, атрибутами тощо» (Василенко, 1996, с. 88). Слід зауважити, що весільний обряд представлено К. Василенком у скороченому, порівняно 3 традиційними формами, вигляді: відсутні магічні ритуали, що характерні для широкоформатної української весільної драми і пов’язані з танцюванням. «Весільний танець» привертає увагу не повнотою зображення українського весілля, адже йдеться про колгоспне весілля, а насиченістю складно-технічними рухами, якими балетмейстер, на нашу думку, прагнув компенсувати дефіцит традиційної весільної обрядовості. За свідченням самого К. Василенка (1996), «у танці було вперше використано на сцені цілий ряд трюкових рухів, комбінацій» (с. 88). Зокрема - це сцена зі сватом, якого піднімають у повітря: четверо юнаків піднімають свата лівими руками, тримаючи за пояс, водночас, тримаючи правими руками за талії чотирьох дівчат, також піднімають їх у повітря. Хлопці рухаються по колу; піднятий угору сват задає ритм танцеві, граючи на гармошці. Окрім традиційних рухів, характерних для Наддніпрянщини, К. Василенко використав цілий набір віртуозних рухів - «бочівочка», закладка з револьтом, «зайчик», різновиди повзунців, стрибки через пояс та ін.; загалом в «Українському весільному танці» використано 39 віртуозних рухів (Василенко, 1996, с. 88). Твір К. Василенка у виконанні заслуженого самодіяльного ансамблю танцю України «Дніпро» 3 міста Дніпродзержинськ (нині - Кам’янське) здобув золоту медаль на Шостому всесоюзному фестивалі молоді та студентів у Москві (Василенко, 1996, с. 89). Оцінюючи цей танець, ми повинні враховувати, що він був твором свого часу й загалом правдиво відображав колгоспний побут і радянську обрядовість. Однак окремі художні знахідки балетмейстера, зокрема, в аспекті використання віртуозних рухів, не варто забувати. Можна й надалі нагромаджувати приклади розвитку віртуозної техніки у народно-сценічній хореографії радянської доби при створенні хореографічних композицій, більшою чи меншою мірою пов'язаних із традиційною основою. Але й наведених прикладів досить, щоб означити ускладнення лексики народно-сценічного танцю як одну із провідних тенденцій хореографічного мистецтва радянської доби. 
Наукова новизна. Уперше проаналізовано віртуозну лексику українського народно-сценічного танцю в діяльності ансамблів народного танцю України за радянської доби крізь історико-культурну призму.

Висновки. У річищі соціалістичного реалізму, проголошеного провідним естетико-культурним орієнтиром мистецької сфери на початку 30-х pp. XX ст. в СРСР, створення професійних та аматорських ансамблів народного танцю відбулося під гаслом збереження національної ідентичності. Одночасно український народно-сценічний танець перетворювався на один з інструментів радянської пропаганди.

Творчість К. Балог, К. Василенка, П. Вірського, Л. Калініна, А. Кривохижі, В. Петрика, Я. Чуперчука та інших балетмейстерів в аматорських та професійних ансамблях народного танцю в радянський період дає підстави вести мову про виокремлення феномену віртуозності в народно-сценічному танці, що є віддзеркаленням однієї із провідних тенденцій хореографічного мистецтва - ускладнення лексики народно-сценічного танцю.

У контексті мистецтва соціалістичного реалізму феномен віртуозності мав суперечливу природу: $з$ одного боку, ускладнення традиційних і використання нових віртуозних рухів з арсеналу класичного балету, взаємодія зі спортом засвідчували процес розвитку віртуозної лексики народно-сценічного танцю, збагачення його виражальних засобів; з іншого боку - віртуозність у радянський час була замінником вихолощеного традиційного змісту народного танцю.

\section{СПИСОК БІБЛІОГРАФІЧНИХ ПОСИЛАНЬ}

Боримська, Г. (1974). Самоцвіти українського танцю. Київ: Мистецтво.

Вантух, М.М. (2002). Стан народної хореографії в Україні та перспективи іï розвитку. В Стан народної хореографії в Україні та перспективи їі розвитку, матеріали науково-практичної конференції (с. 15-23). Київ: Стилос.

Василенко, К. (1996). Лексика українського народно-сценічного танцю. Київ: Мистецтвво.

Верховинець, В.М. (1990). Теорія українського народного танцю. Київ: Музична Україна.

Вірський, П.П. (1960). Думки і поради. Мистецтво, 3, 15.

Керженцев, П. (1936, 22 марта). Итоги украинской декады. Правда.

Кіптілова, Н. (2014). Гопак як один з феноменів українського танцю. Вісник Львівського університету. Серія мистецтвознавство, 14, 75-80.

Колосок, О.П. (2002). Специфіка роботи балетмейстера у народному хорі. В Стан народної хореографії в Україні та перспективи їі розвитку, матеріали науково-практичної конференції (с. 25-30). Київ: Стилос.

Купленник, В. (1997). Нариси до історії українського народного танцю. Київ: ІЗМН.

Литвиненко, В.Н. (2009). Творчість П. П. Вірського у міжнародному інформаційному просторі. Вісник КНУКіМ. Мистецтвознавство, 20, 65-72.

Морозов, А.І. (2014). До проблеми вивчення чоловічих віртуозних рухів в українському народно-сценічному танці. Мистещтвознавчі записки, 26, 309-316.

Морозов, А.I. (2017). Віртуозні рухи як феномен народного хореографічного мистецтва. Молодий вчений, 8(48), 60-63. 
Патон, Б.Є., Ажнюк, Б.М., Бондар, М.П., Горбачов, Д.О., Дзюба, І.М., Жулинський, М.Г. ... Сулима, М.М. (Ред.). (2011). Історія української культури (Т. 5, Кн. 1). Київ: Наукова думка.

Підлипська, А. (2018). Український народно-сценічний танець «Гопак»: науково-теоретичний та художньо-критичний аспекти. Мистецтвознавчі записки, 34, 151-158.

Посадов, А. (1937, 2 грудня). Державний ансамбль народного танцю. Bicmi.

Рильський, М.Т. (1990). Чародій танцю. В В.М. Верховинець, Теорія українського народного танцю (с. 5-6). Київ: Музична Україна.

Різник, О. (1998). Танець. Нариси української популярної культури. Київ: УЦКД.

Шкоріненко, В.О. (2003). Народний танець у традиційній і сучасній культурі України. (Автореферат дисертації кандидата мистецтвознавства). Державна академія керівних кадрів культури і мистецтв, Київ.

\section{REFERENCES}

Borymska, H. (1974). Samotsvity ukrainskoho tantsiu [Gems of Ukrainian dance]. Kyiv: Mystetstvo [in Ukrainian].

Kerzhentsev, P. (1936, March 22). Itogi ukrainskoy dekady [The results of the Ukrainian decade]. Pravda [in Russian].

Kiptilova, N. (2014). Hopak yak odyn z fenomeniv ukrainskoho tantsiu [Hopak as one of the phenomena of Ukrainian dance]. Visnyk of the Lviv University. Series Art Studies, 14, 75-80 [in Ukrainian].

Kolosok, O.P. (2002). Spetsyfika roboty baletmeistera u narodnomu khori [Specificity of ballet master's work in folk choir]. In Stan narodnoi khoreohrafii $v$ Ukraini ta perspektyvy yii rozvytku [The state of folk choreography in Ukraine and prospects for its development], Proceedings of the Conference (pp. 25-30). Kyiv: Stylos [in Ukrainian].

Kuplennyk, V. (1997). Narysy do istorii ukrainskoho narodnoho tantsiu [Essays on the History of Ukrainian Folk Dance]. Kyiv: IZMN [in Ukrainian].

Lytvynenko, V.N. (2009). Tvorchist P. P. Virskoho u mizhnarodnomu informatsiinomu prostori [Creativity of P. P. Virsky in the international information space]. Bulletin of KNUKiM. Series in Arts, 20, 65-72 [in Ukrainian].

Morozov, A.I. (2014). Do problemy vyvchennia cholovichykh virtuoznykh rukhiv v ukrainskomu narodno-stsenichnomu tantsi [On the Problem of Studying Male Virtuoso Movements in Ukrainian Folk Dances]. Notes on art criticism, 26, 309-316 [in Ukrainian].

Morozov, A.I. (2017). Virtuozni rukhy yak fenomen narodnoho khoreohrafichnoho mystetstva [Virtuoso movements as a phenomenon of folk choreographic art]. Molodyi vchenyi, 8(48), 60-63 [in Ukrainian].

Paton, B.Ye., Azhniuk, B.M., Bondar, M.P., Horbachov, D.O., Dziuba, I.M., Zhulynskyi, M.H. ... Sulyma, M.M. (Eds.). (2011). Istoriia ukrainskoi kultury [History of Ukrainian Culture] (Vol. 5, Pt. 1). Kyiv: Naukova dumka [in Ukrainian].

Pidlypska, A. (2018). Ukrainskyi narodno-stsenichnyi tanets «Hopak»: naukovo-teoretychnyi ta khudozhno-krytychnyi aspekty [Hopak Ukrainian Folk Dances: Scientific, Theoretical, and Critical Aspects]. Notes on art criticism, 34, 151-158 [in Ukrainian].

Posadov, A. (1937, December 2). Derzhavnyi ansambl narodnoho tantsiu [State folk dance ensemble]. Visti [in Ukrainian].

Riznyk, O. (1998). Tanets. Narysy ukrainskoi populiarnoi kultury [Dance. Essays on Ukrainian Popular Culture]. Kyiv: UTsKD [in Ukrainian]. 
Rylskyi, M.T. (1990). Charodii tantsiu [The Wizard of Dance]. In V.M. Verkhovynets, Teoriia ukrainskoho narodnoho tantsiu [The Theory of Ukrainian Folk Dance] (pp. 5-6). Kyiv: Muzychna Ukraina [in Ukrainian].

Shkorinenko, V.O. (2003). Narodnyi tanets u tradytsiinii $i$ suchasnii kulturi Ukrainy [Folk dance in traditional and modern culture of Ukraine]. (Abstract of PhD Dissertation). State Academy of Managerial Staff of Culture and Arts, Kyiv [in Ukrainian].

Vantukh, M.M. (2002). Stan narodnoi khoreohrafii v Ukraini ta perspektyvy yii rozvytku [State of folk choreography in Ukraine and prospects for its development]. In Stan narodnoi khoreohrafii v Ukraini ta perspektyvy yii rozvytku [The state of folk choreography in Ukraine and prospects for its development], Proceedings of the Conference (pp. 15-23). Kyiv: Stylos [in Ukrainian].

Vasylenko, K. (1996). Leksyka ukrainskoho narodno-stsenichnoho tantsiu [Vocabulary of Ukrainian folk-dance]. Kyiv: Mystetstvo [in Ukrainian].

Verkhovynets, V.M. (1990). Teoriia ukrainskoho narodnoho tantsiu [The theory of Ukrainian folk dance]. Kyiv: Muzychna Ukraina [in Ukrainian].

Virskyi, P.P. (1960). Dumky i porady [Thoughts and tips]. Mystetstvo, 3, 15 [in Ukrainian]. 